\title{
Elementary Teachers' Perceptions of Engineering and Engineering Design
}

\author{
Rebekah Hammack ${ }^{\mathrm{a} 1}$,Toni Ivey ${ }^{\mathrm{b}}$ \\ ${ }^{\mathrm{a}}$ Montana State University, USA ${ }^{\mathrm{b}}$ Oklahoma State University, USA
}

\begin{abstract}
The Next Generation Science Standards (NGSS) call for the infusion of engineering practices beginning in Kindergarten, yet little is known about how prepared elementary teachers are to incorporate these standards. The purpose of this study was to identify (a) the perceptions that in-service teachers hold about the nature of engineering and engineering design and (b) how these perceptions compare with the engineering practices put forth in NGSS. This study is part of a larger explanatory sequential mixed methods design. Study participants included $542 \mathrm{~K}-5$ public school teachers who were responsible for the science instruction of their students. During the first phase of the study, participants completed an online questionnaire consisting of Likert, selected response, and openended items. The results of the survey were used to finalize interview protocols for the second phase, which consisted of follow-up focus group and interview sessions with a subset of the survey participants. Findings indicated that participants were unfamiliar with engineering or engineering design and held stereotypical misconceptions about the work of engineers. Many participants reported having little experience teaching engineering and were not able to distinguish between examples of science and engineering activities. In short, findings indicated that teachers' perceptions of engineering and engineering design do not align with the engineering practices and disciplinary core ideas found in NGSS.
\end{abstract}

Keywords: Elementary teachers, engineering education, teacher perceptions

\section{Introduction}

As the world becomes increasingly dependent on technology, nations' demands for workers in the areas of science technology, engineering, and mathematics (STEM) has increased (International Technology Education Association, ITEA, 2007). To help address these demands, the National Research Council (NRC, 2012) released A Framework for K-12 Science Education: Practices, Crosscutting Concepts, and Core Ideas in which they identified key scientific and engineering practices that all students should learn during K-12 education. The Next Generation Science Standards (NGSS) (NGSS Lead States, 2013) were developed based on the practices identified in the Framework. The NGSS call for the infusion of engineering practices into $\mathrm{K}-12$ science classrooms; however, little is known about the preparedness of elementary teachers to incorporate these engineering standards. Available research suggests that elementary teachers feel unprepared to teach engineering practices (Banilower, Smith, Weiss, Malzahn, Campbell, \&Weis, 2013; Sargianis, Yang, and Cunningham, 2012). One national survey indicated that only $4 \%$ of elementary teachers felt very well prepared

${ }^{1}$ Corresponding author. Montana State University, Department of Education, Bozeman, Orlando, MT 59717 E-mail: rebekah.hammack@montana.edu Hammack, R., \& Ivey, T. (2016). Elementary teachers' perceptions of engineering and engineering Design. Journal of Research in STEM Education, $3(1 / 2), 48-68$. 
to teach engineering to their students. This is considerably lower than the $39 \%$ who felt very well prepared to teach science and $77 \%$ for mathematics (Banilower et al., 2013).

Most teacher preparation programs do not prepare elementary teachers to incorporate engineering concepts and practices into their teaching, and in-service programs focused on engineering for elementary teachers are limited. Determining the perceptions that elementary teachers have of engineering, as well as their understanding of engineering design, will be vital to ensuring that teachers receive the proper professional development to successfully implement engineering concepts and practices in their classrooms. The development of such programs should be rooted in the research literature related to elementary engineering education, however, that body of literature is far from complete. The current study helps address gaps in the research literature by describing elementary teachers' perceptions of engineering and engineering design.

\section{Purpose of the Study}

The purpose of this study was to identify (a) the perceptions that in-service teachers hold about the nature of engineering and engineering design and (b) how these perceptions compare with the engineering practices put forth in A Framework for K-12 Science Education and Next Generation Science Standards. Specifically, the study sought to answer the following research questions: 1) How familiar are in-service elementary teachers with engineering and engineering design?, 2) What perceptions do in-service elementary teachers hold about engineers and engineering design?, 3) Are there differences in teachers' familiarity with engineering or perceptions of engineers between different demographic groups?, and 4) How do in-service elementary teachers' perceptions of engineering and engineering design compare with expectations set by K-5 engineering education standards?

\section{Related Literature}

\section{Next Generation Science Standards (NGSS)}

The NGSS are comprised of three dimensions: Science and Engineering Practices, Crosscutting Concepts, and Disciplinary Core Ideas. In NGSS, each of the standards is a performance expectation that incorporates all three dimensions. Table 1 presents the three dimensions of the Framework and NGSS as well as the components of each dimension. Table 2 presents the component ideas that make up Disciplinary Core Idea: Engineering, Technology, and Applications of Science (NGSS Lead States, 2013). The information presented in Tables 1 and 2 can be used as a framework to determine the knowledge $\mathrm{K}-12$ teachers will need in order to implement engineering concepts and practices into their classrooms.

Table 1.

Dimensions of the Framework and NGSS

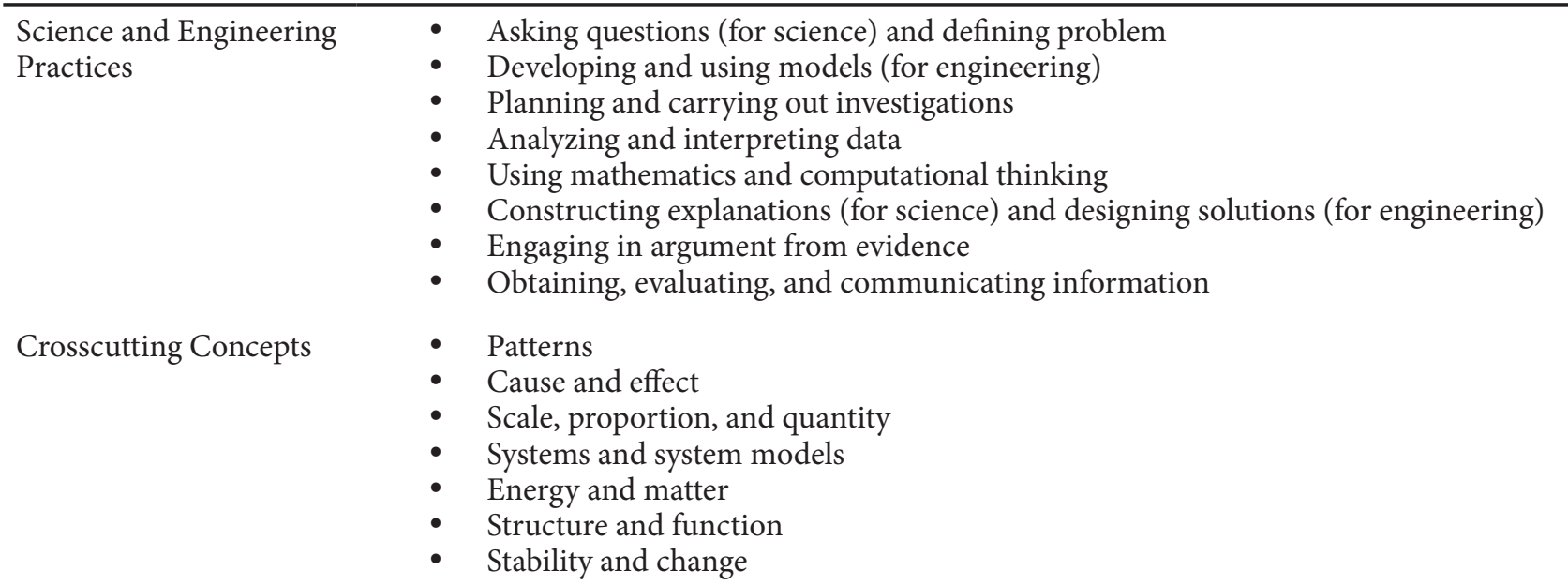




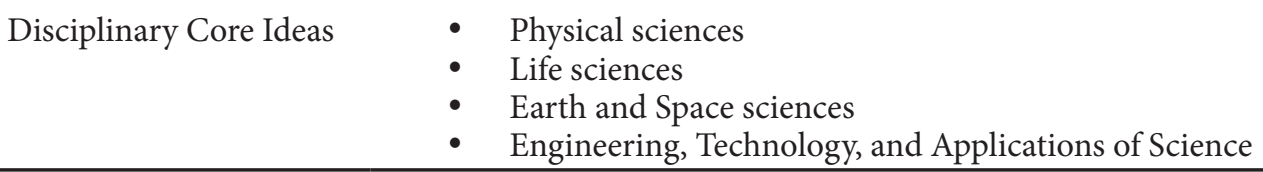

Table 2.

Core and Component Ideas in Engineering, Technology, and Applications of Science

\begin{tabular}{lll} 
Disciplinary Core Idea & Core Idea & Component Idea \\
\hline $\begin{array}{l}\text { Engineering, Technology, and } \\
\text { Applications of Science }\end{array}$ & $\begin{array}{l}\text { ETS1: Engineering De- } \\
\text { sign }\end{array}$ & $\begin{array}{l}\text { ETS1.A: Defining and Delimiting an Engineering Prob- } \\
\text { lem }\end{array}$
\end{tabular}

ETS1.B: Developing Possible Solutions

ETS1.C: Optimizing the Design Solutions

ETS2: Links Among En- ETS2.A: Interdependence of Science, Engineering , and gineering, Technology, Technology

Science, and Society

ETS2.B: Influence of Engineering, Technology, and Science on Society and the Natural World

\section{Perceptions of Engineers}

Many Americans do not understand what engineering is and often confuse the work of engineers with the work of scientists, construction workers, or mechanics (Oware, Capobianco, \& Diefes-Dux, 2007). This lack of understanding leads to misconceptions that could prevent talented adolescents form entering the engineering pipeline. Studies employing the Draw-an-Engineer (DAE) instrument (Knight\& Cunningham, 2004) highlight the stereotypical misconceptions that children hold about engineering. Children often perceive engineers as people who build and fix things and are much more likely to create drawings of white, male engineers who are working alone than drawings of women, minorities, or people working in groups (Pekmez, 2018; Newley, Kaya, Yesilyurt, \& Deniz, 2017; Hammack and High, 2014; Karatas, Micklos, \& Bodner, 2011; Fralick, Kearn, Thompson, \& Lyons, 2009).

Adults are prone to similar preconceptions about the nature of engineering (Liu, Carr, \& Strobel, 2009). In fact, K-12 teachers are more likely to believe that engineers are the people constructing a building than the ones supervising the construction (Cunningham, Lachapele, \& Lindgren-Stricher, 2006). Additionally, when asked to describe engineering, few K-6 grade teachers described engineering as being linked to science and mathematics, involving teamwork and communication, or being creative (Lambert, Diefes-Dux, Beck, Duncam, Oware, \& Nemeth, 2007), all of which are related to the three general principles of engineering education put forth by the Committee on Standards for K-12 Engineering (2010).

Research findings indicate that teachers' perceptions toward science influence students' perceptions toward science, and likewise, it is expected that teachers' perceptions of engineering will influence students' perceptions of engineering (Lambert et al., 2007). Teachers' limited understanding of engineering impacts their perceptions of engineering (Yasar, Baker, Kurpius-Robinson, Krause, \& Roberts, 2006) which can be passed on to their students. Due to a limited understanding of engineering, elementary teachers often do not view engineering as an appropriate career choice for all students (Brophy et al., 2008), believing that only "super smart" teachers and students can learn engineering concepts (Cunningham, 2009), and place less value on teaching engineering design than secondary teachers do (Yasar et al., 2006). In fact, Van Haneghan, Pruet, Neal-Waltman, and Harlan (2015) found that even middle school teachers do not believe that the majority of their students have the ability to achieve competency in engineering content. This may result in teachers 
focusing their efforts on content they feel will benefit all students and not just the few who they view as capable of becoming engineers (Brophy, Klein, Portsmore, \& Rogers, 2008). Additionally, teachers who have a narrow view of engineering might misrepresent engineering careers to their students, thus missing the opportunity to encourage students to enter the STEM pipeline (Yasar et al., 2006)

\section{Teaching Engineering Design}

Teachers are uncomfortable teaching what they do not know or are unfamiliar with (Brophy et al., 2008). Because many pre-kindergarten through eighth grade teachers have limited STEM content knowledge (Brophy et al., 2008), they may avoid teaching engineering. While working with teachers in Scotland, Harlen and Holroyd (1997) determined that elementary teachers employed coping strategies when they did not feel confident in their abilities to teach science content. Examples of the coping strategies included: (a) placing as little of the content as possible in the weekly lesson plans so the content could be the first item removed if the class is behind schedule; (b) compensating for low confidence areas (e.g. physical science) by teaching more high confidence content (e.g. life science); (c) relying heavily on worksheets or kits that have step-by-step instructions; and (d) emphasizing teacher-centered instruction with little opportunity for student questions or discussions (Harlen \& Holroyd, 1997). It is expected that teachers would employ similar coping strategies when faced with teaching engineering content with which they are unfamiliar.

Regardless of grade level or subject taught, effective classroom instruction requires the teacher to possess subject matter content knowledge (SMCK), curricular knowledge (CK), and pedagogical content knowledge (PCK) (Shulman, 1986). SMCK refers to knowledge of the component facts and concepts of a subject as well as the ways in which the facts and concepts are arranged and validated. CK refers to a knowledge of the instructional resources available for teaching a subject. Shulman (1986) defined PCK as "the ways of representing and formulating the subject that make it comprehensible to others" (p. 9). PCK includes an understanding of what makes particular concepts difficult to understand and the preconceptions and misconceptions students have about a subject.

Design is the fundamental activity of engineering (Petroski, 2003) and teaching engineering design requires SMCK, CK, and PCK. Teachers who are unfamiliar with the nature of engineering design will be unable to address engineering design standards or identify ways to infuse engineering into their curriculum (Baker, Yasar-Purzer, Kurpius, Krause, \& Roberts, 2007). The open-ended nature of engineering design means that design challenges do not have a single solution. Teachers must assess engineering design activities not only by how well the developed design solution solves the problem, but also by the processes the students went through to develop the solution (Brophy et al., 2008). Teachers with greater PCK are better able to determine children's understandings by observing their behaviors and performances, and use that information to modify class instruction (Bischoff, 2006). Many elementary teachers have never taught using open-ended problems that do not have a single "correct" answer (Cunningham, 2009) and may lack the PCK to effectively teach using open-ended engineering design challenges.

SMCK and PCK are required for teachers to understand real-world applications of content and to design effective instruction (Davis, 2003). Engineering design is an iterative process (Schunn, 2009; Silk \& Schunn, 2008), and when students are given the opportunity to redesign, they develop a more complete understanding of the related engineering concepts (Schunn, 2009). Short duration exposures to engineering are not likely to lead to meaningful learning (Schunn, 2009) because they do not provide students with the opportunity to learn from their mistakes. In order to facilitate redesign activities, however, teachers must possess appropriate knowledge to help students identify the weaknesses in their original designs and ways to improve upon those designs. Additionally, it is critical that design lessons require the application of math and science and are situated within real-world contexts (Guzey, Tank, Wang, Roehrig, \& Moore, 2014) which require teachers to possess SCMC, CK, and PCK related to engineering. 


\section{Method}

The current study is part of a larger mixed methods research study. Mixed methods research refers to any study that involves the collection, analysis, and interpretation of both qualitative and quantitative data (Creswell \& Plano Clark, 2011). Both quantitative and qualitative data were used to compare the results from different phases of the study and provide greater insight into the problem being studied than by using a single method.

During the first phase, participants completed an online questionnaire containing both open and closedended questions. Concurrently, the Next Generation Science Standards document was reviewed to determine the knowledge required for elementary teachers to implement the engineering components required by the standards. The results from Phase 1 were used to finalize the interview protocols used during the individual and focus group sessions that took place during Phase 2 of the study. Data from both phases were triangulated to answer the research questions related to teachers' perceptions of engineering and engineering design and how these perceptions compare with the expectations set forth in NGSS.

\section{Measures}

Because the researchers were unable to identify a validated instrument that would fully answer each of the proposed research questions in the full study, subscales from existing validated instruments were combined. These included the Teaching Engineering Self-efficacy Scale (TESS) (Yoon et al., 2014); Design, Engineering, and Technology Scale (DET) (Yasar et al., 2006); and Engineering Design Self-efficacy Instrument (EDSI) (Carberry et al., 2010). Only those subscale questions which were pertinent to answering the current research questions are included in this study. The data analyzed in the current study come from the Familiarity with Design Engineering and Technology and Stereotypical Characteristics of Engineers subscales from the Design Engineering and Technology Survey (Appendix A), as well as two open-ended researcher generated questions (What words or phrases would you use to describe the characteristics of a typical engineer? and What do engineers do as part of their work?).

\section{Design Engineering and Technology Survey (DET)}

The DET was originally developed by Yasar, Baker, Robinson-Kurpius, Krause, and Roberts (2006) and later re-evaluated and revised by Hong et al. (2011). The DET contains 40 items on a five point Likert scale, and is used to measure teachers' perceptions of engineering and familiarity with teaching engineering, engineering design, and technology. Exploratory factor analysis using a new sample of 405 participant teachers resulted in a 40 -item four-factor instrument with an overall Cronbach's $\alpha=0.88$. The resulting factors were Importance of DET (19 items, $\alpha=0.91$ ), Familiarity with DET ( 8 items, $\alpha=0.81$ ), Stereotypical Characteristics of Engineers (7 items, $\alpha=0.77$ ), and Barriers to Integrating DET ( 6 items, $\alpha=0.68$ ). The Familiarity with DET subscale and Stereotypical Characteristics of Engineers subscale were the only DET subscales included in the current study.

\section{Participants}

A link to the questionnaire was emailed to all Oklahoma K-5 public school teachers ( $n=16,546)$ whose information was on file with the Oklahoma State Department of Education, however 1,008 emails were returned undeliverable. The questionnaire was completed by 542 participants resulting in a $3.5 \%$ response rate. Table 3 presents demographic information for the sample. Oklahoma encompasses a large geographic region with both urban and rural populations, and the researchers wanted to ensure that the sample was representative of the geographic distribution of the state population. The Oklahoma State Department of Education has assigned all school districts in the state to one of eight geographic regions, which were used to evaluate the geographic distribution of the sample. The data in Table 3 reveal that the sample was representative of the state population of elementary teachers with regard to geographic distribution of teachers, gender, education level, grade level taught, and years of work experience. 
Table 3.

Demographics of Oklahoma K-5 Teacher Population and Study Sample

\begin{tabular}{|c|c|c|c|c|c|}
\hline & \multicolumn{3}{|c|}{ Population } & \multicolumn{2}{|c|}{ Sample } \\
\hline & & Number & Percentage & Number & Percentage \\
\hline \multicolumn{6}{|l|}{ Oklahoma Geographic Region } \\
\hline & 1 & 670 & 4.03 & 26 & 4.80 \\
\hline & 2 & 1181 & 7.10 & 48 & 8.86 \\
\hline & 3 & 3538 & 21.28 & 159 & 29.34 \\
\hline & 4 & 2180 & 13.11 & 55 & 10.15 \\
\hline & 5 & 1049 & 6.31 & 18 & 3.32 \\
\hline & 6 & 1384 & 8.32 & 37 & 6.83 \\
\hline & 7 & 1058 & 6.36 & 30 & 5.54 \\
\hline & 8 & 5567 & 33.48 & 169 & 31.18 \\
\hline
\end{tabular}

Gender

$\begin{array}{rrrrr}\text { M } & 698 & 4.20 & 16 & 3.00 \\ \mathrm{~F} & 15929 & 95.80 & 526 & 97.00\end{array}$

Highest Education Level

$\begin{array}{rrrrr}\text { Bachelor's } & 13090 & 78.73 & 381 & 70.30 \\ \text { Master's/Education Specialist } & 3498 & 21.04 & 157 & 28.97 \\ \text { Doctorate } & 36 & 0.22 & 4 & 0.74 \\ \text { N/A } & 3 & 0.01 & 0 & 0.00\end{array}$

Work Experience

(Years)

$\begin{array}{rrr}1 \text { to } 5 & 4926 & 29.63 \\ 6 \text { to } 10 & 3501 & 21.06 \\ 11 \text { to } 15 & 2506 & 15.07 \\ 16 \text { to } 20 & 2224 & 13.38 \\ 21 \text { to } 25 & 1613 & 9.70 \\ 26 \text { to } 30 & 912 & 5.49 \\ 31 \text { to } 35 & 534 & 3.21 \\ 36-40 & 323 & 1.94 \\ \text { over } 40 & 88 & 0.53\end{array}$

163

30.07

1.06

20.48

111

15.68

13.38

12.73

69

8.86

7.01

2.77

$21-15$

1.85

0.53

0.55

Certification Type

$\begin{array}{rrrrr}\text { Traditional } & 15951 & 95.93 & 491 & 90.59 \\ \text { Nontraditional } & 676 & 4.07 & 51 & 9.41\end{array}$

Grade Level Taught

\begin{tabular}{rrrrr}
$\mathrm{K}$ & 3176 & 19.10 & 91 & 16.79 \\
1 & 3638 & 21.88 & 98 & 18.08 \\
2 & 3601 & 21.66 & 102 & 18.82 \\
3 & 3658 & 22.00 & 112 & 20.67 \\
4 & 3370 & 20.27 & 120 & 22.14 \\
5 & 3527 & 21.21 & 98 & 18.08 \\
\hline
\end{tabular}




\section{Data Analysis}

Quantitative data from the questionnaire, qualitative data from the questionnaire, and the NGSS document were analyzed separately and then triangulated to look for convergence or divergence of findings (Creswell \& Plano Clark, 2011). Additionally, the qualitative data from the interviews and focus group sessions collected during Phase 2 were analyzed independently of the other data and then triangulated with the Phase 1 data to further explain and expand the analysis from Phase 1.

\section{Quantitative Data Analysis}

Participant responses for the DET questions were transferred to SPSS and analyzed. Cronbach's a was computed to determine the internal consistency of each DET subscale. Computed values for Familiarity with DET $(\alpha=.90)$ and Stereotypical Characteristics of Engineers $(\alpha=.85)$ were higher than those reported by Hong et al. (2011). The researchers analyzed the DET subscale data to yield frequencies of respondents choosing each response category. Box and whiskers plots were created to visually display DET subscale data. Researchers used one-way ANOVA to determine if any significant differences existed on subscale scores of different demographic groups including grade level taught, gender, pathway to certification, ethnicity, grade level taught, education attainment level, geographic region, and years of teaching experience. ANOVA assumes equality of variance, therefore, the Levene's test for equality of variance was run before interpreting the results of the one-way ANOVA. When the assumption of equal variances was violated (Levene's test less than .05), the Welch test, which does not assume equal variances, was used.

\section{Qualitative Data Analysis}

Qualitative data included the open-ended questionnaire responses and focus group and interview transcripts.

\section{Open-ended questionnaire responses}

Responses to the two open-ended questions "What words or phrases would you use to describe the characteristics of a typical engineer?" and "What do engineers do as part of their work?" were printed onto cards which were used during the coding process (Creswell, 2007). First, attribute coding was used to log essential demographic information about the participants for future reference (Saldana, 2013). Each card was coded with the participant's gender, ethnicity, years of teaching experience, education attainment level, geographic region, pathway to certification, and grade level taught. Next, a Wordle (www.wordle.net) was created for each open-ended question and used to create an initial visual representation of the data and identify the most salient words to use as initial codes. In a Wordle, words that appear more frequently in the data set are displayed using a larger font. This provides a quick visual representation of the frequency with which different words are used. However, Wordles are impacted by spelling, punctuation, and conjugates of words, which impact the visual display. For example, problem solver and problem solving would not be grouped together because they are not exact matches. McNaught and Lam (2010) found that word clouds, such as Wordles, are useful tools for preliminary qualitative data analysis, however they should not be used as the only method of analysis due to the way in which the word clouds are generated.

After generating Wordles, the researchers used the initial code list to complete a round of descriptive coding as described by Saldana (2013). During this first round of descriptive coding, additional codes were generated and added to the initial code list and code frequencies were determined. As suggested by Namey, Guest, Thairu, and Johnson (2008), the frequencies with which each code appeared in the data were based on the number of participants who used a particular code, not the number of times that the code appeared. 


\section{Focus groups and interviews}

Upon completion of the online questionnaire, participants were redirected to an unlinked survey where they could provide contact information if they wished to participate in a follow-up interview or focus group. Based on individual availability, three focus groups were scheduled in two different large cities in the state, with seven to ten individuals scheduled for each session. Actual focus group attendance was low, with four individuals participating in the first focus group and the last two focus group sessions becoming individual interviews. A total of 11 individual interviews were conducted, two in person, and nine over the phone. The researchers wrote field notes during each session, reviewed the notes immediately following each follow-up session, and used the field notes to write a reflection over the session.

All focus group and interview sessions were audio recorded and transcribed verbatim by the researcher who conducted the interview (Oliver, Serovich, \& Mason, 2005). To ensure that the findings remained true to the participants' perspectives, each participant was provided with a copy of the transcript to allow for member checking. Changes were made to the transcripts based on participants' feedback. During transcript analysis, the researchers did not force the data into predetermined categories. Rather, they inductively coded the individual transcripts using a data-driven approach (Brinkmann, 2013) during which they developed codes as they read over the raw data transcripts. Later, focused coding was used to organize the initial data into categories and compare the codes across participants' transcripts (Saldana, 2013).

\section{Trustworthiness and Credibility}

Creswell (2007) identifies eight validation strategies for qualitative research - prolonged engagement in the field; triangulation; peer review; negative case analysis; clarifying researcher bias at the beginning of the study; member checking; rich, thick descriptions; and external audits - and recommend the use of at least two of them in every qualitative study. In the current study, the researchers used provided participants with the opportunity to review the researchers' written description and interpretation of the interviews and focus group sessions (member checking) and triangulation. According to Merriam (2009), there are four processes of triangulation that can be implemented during a study: a) the use of multiple methods, b) the use of multiple sources of data, c) the use of multiple investigators, and/or d) the use of multiple theories to confirm emerging findings, through which validity and reliability can be achieved. For this study, triangulation was achieved through the use of multiple methods (quantitative and qualitative), multiple sources of data (NGSS document, survey data, interview and focus group transcripts), and the use of multiple reviewers, known as investigator triangulation. Investigator triangulation is defined as the process of using two or more reviewers to review and define the codes and themes in order to establish inter-rater reliability (Merriam, 2009). The researchers established inter-rater reliability by independently analyzing qualitative data, compare the resulting codes and themes, and discussing resulting codes and themes until consensus was reached.

\section{Results}

When answering our research questions, we first analyzed the qualitative and quantitative data separately and then merged the two to come to a deeper understanding of the underlying phenomena. Our findings are presented in a similar manner, with the qualitative and quantitative findings reported separately in the results section and then merged and described in the discussion section.

\section{Quantitative data}

Figure 1 provides box and whiskers plots of the Familiarity with DET and Stereotypical Characteristics of Engineers subscale data. Seventy-five percent of participants had a mean subscale score at or below 2.5 on the Familiarity with DET subscale. This, combined with the overall mean score of 1.99 on the Familiarity with DET 
subscale, suggests that participants were not very familiar with design, engineering, and technology. The mean score on the Stereotypical Characteristics of Engineers was 4.30 and 95\% of participants scored at least 3.0, indicating that participants held stereotypical views of engineers. Pearson correlation reveal that Familiarity with DET and Stereotypical Characteristics of Engineers were significantly correlated with each other $(\mathrm{r}=$ $.13, \mathrm{p}=.002$ ), however the small $\mathrm{r}$ value may indicate low practical significance. ANOVA revealed that male participants had significantly higher Familiarity with DET than female participants, $\mathrm{F}(1,541)=9.828, \mathrm{p}=.002$, $\eta 2=.01$. No other significant differences were found between demographic groups.
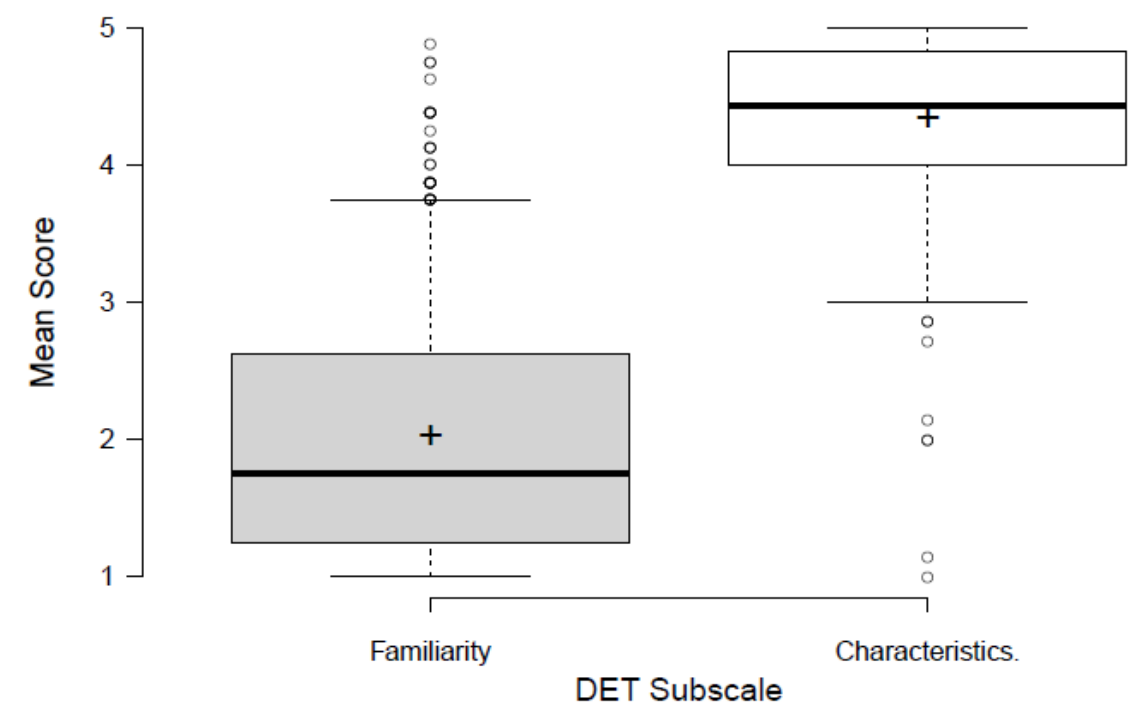

Figure 1. Mean Design/Engineering/Technology (DET) subscale data. The whiskers extend from the 5th to 95th percentile scores and the “+” represents the mean.

Figure 2 provides a breakdown of participant responses by Likert level for each of the questions on the Familiarity with DET subscale. Please refer to Appendix C for a full list of subscale questions. The responses clearly illustrate that the majority of participants did not have preservice coursework for DET and left their preservice curriculum not feeling prepared to teach engineering. The majority of participants also rated their DET confidence low, reported that they did not use DET activities in their classrooms, and did not have a support system at school to help them implement DET activities. 


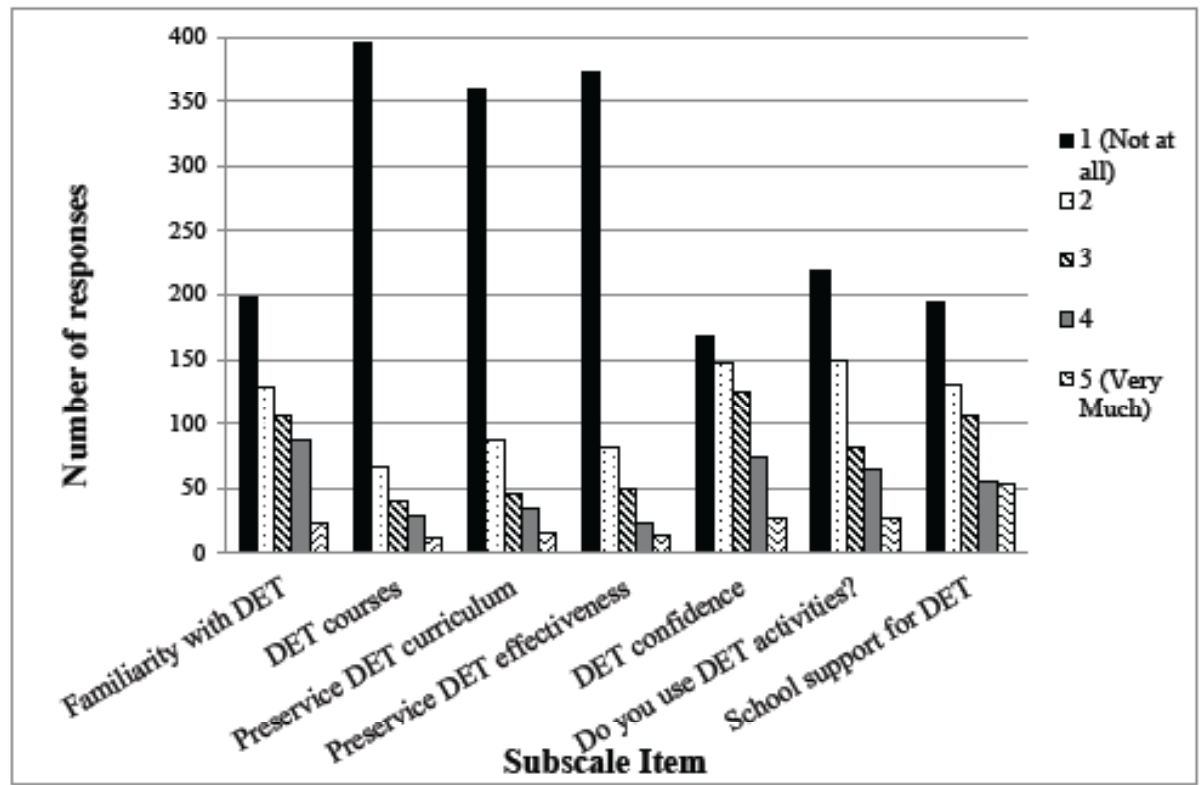

Figure 2. Participant responses for each item on the Familiarity with Design/Engineering/ Technology subscale.

Figure 3 provides a breakdown of participant responses for each item on the Stereotypical Characteristics of Engineering subscale of the DET instrument. Visual inspection of the individual items in Figure 3 reveals that participants viewed engineers as people who have good math and science skills, earn good money, and like to fix things. However, fewer participants strongly agreed that engineers work well with other people and have good communication skills (verbal and written).

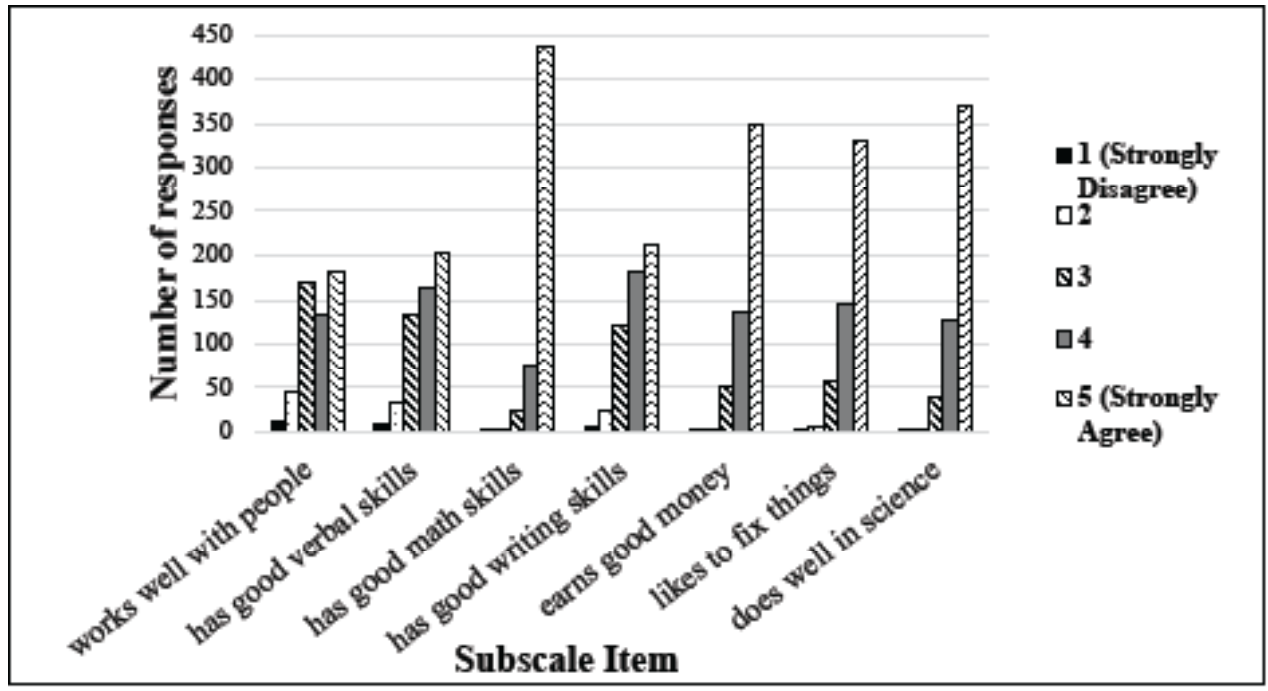

Figure 3. Participant responses for each item on the Stereotypical Characteristics of Engineers subscale.

\section{Qualitative Data Analysis}

Open-ended responses

Most participant responses to the open-ended questions fell within one or more of the following nine categories - Engineers as Thinkers, Engineers as Creators, Engineers as Doers, Engineers as Managers, Engineers are Motivated, Engineers are Tech Savvy, Engineers as Social Beings, Types of Engineers, and Uncertainty. It was common for a participants' responses to fall into multiple categories. Table 4 presents a description of each category and examples of representative codes that fell within each category. 
Table 4.

Category descriptors and illustrative codes for open-ended responses

\begin{tabular}{|c|c|c|}
\hline Category & Description & Codes (and frequencies) in category \\
\hline $\begin{array}{l}\text { Engineers as } \\
\text { Thinkers }\end{array}$ & $\begin{array}{l}\text { Response focuses on the use or } \\
\text { application of knowledge }\end{array}$ & $\begin{array}{l}\text { problem solver }(n=307) \text {, math }(n=222) \text {, intelligent }(n= \\
\text { 127), research }(n=109) \text {, science }(n=79) \text {, analytical }(n= \\
\text { 52), logical }(n=37) \text {, critical thinker }(n=23) \text {, optimize }(n \\
=22) \text {, curious or inquisitive }(n=21) \text {, spatial reasoning ( } \\
=20) \text {, thinking outside of the box }(n=17) \text {, high level of } \\
\text { education }(n=14), \text { methodical }(n=6) \text {, reasoning abilities } \\
(n=5) \text {, intuitive }(n=4) \text {, systematic thinkers }(n=3) \text {, } \\
\text { pragmatic }(n=2)\end{array}$ \\
\hline $\begin{array}{l}\text { Engineers as } \\
\text { Creators }\end{array}$ & $\begin{array}{l}\text { Response focuses on creative } \\
\text { processes }\end{array}$ & $\begin{array}{l}\text { designer }(n=273) \text {, creative }(n=249) \text {, innovative }(n= \\
81) \text {, inventive }(n=46) \text {, develop ideas }(n=7) \text {, visual and } \\
\text { artistic }(n=6)\end{array}$ \\
\hline $\begin{array}{l}\text { Engineers as } \\
\text { Managers }\end{array}$ & $\begin{array}{l}\text { Response describes engineers } \\
\text { as those who oversee work OR } \\
\text { describe qualities needed to } \\
\text { manage }\end{array}$ & $\begin{array}{l}\text { planner }(\mathrm{n}=73) \text {, detail oriented }(\mathrm{n}=43) \text {, leads/oversees } \\
(\mathrm{n}=31) \text {, organized }(\mathrm{n}=27) \text {, safety }(\mathrm{n}=12)\end{array}$ \\
\hline Engineers as Doers & $\begin{array}{l}\text { Response describes the } \\
\text { engagement in hands-on or } \\
\text { physical work }\end{array}$ & $\begin{array}{l}\text { work on structures }(n=55) \text {, Construct } / \text { make/build ( } \mathrm{n} \\
=22) \text {, maintain/repair/fix things }(\mathrm{n}=20) \text {, mechanically } \\
\text { inclined }(\mathrm{n}=20) \text {, work with hands }(\mathrm{n}=15) \text {, use tools }(\mathrm{n} \\
=3 \text { ) }\end{array}$ \\
\hline Types of Engineers & $\begin{array}{l}\text { Response describe work done } \\
\text { by different types of engineers } \\
\text { OR mentions there are different } \\
\text { types of engineers }\end{array}$ & types of engineers $(n=63)$ \\
\hline $\begin{array}{l}\text { Engineers are Tech } \\
\text { Savvy }\end{array}$ & $\begin{array}{l}\text { Response refers to the } \\
\text { development or use of } \\
\text { computers or other high tech } \\
\text { gadgets }\end{array}$ & Computers $(n=28)$, technology $(n=19)$ \\
\hline $\begin{array}{l}\text { Engineers as Social } \\
\text { Beings }\end{array}$ & $\begin{array}{l}\text { Response describes engineers } \\
\text { as either working with or } \\
\text { communicating with others OR } \\
\text { describes personality traits }\end{array}$ & $\begin{array}{l}\text { team work }(\mathrm{n}=31) \text {, communication }(\mathrm{n}=7) \text {, nerdy }(\mathrm{n}= \\
2) \text {, anti-social behaviors }(\mathrm{n}=2) \text {, corky }(\mathrm{n}=1) \text {, introverted } \\
(\mathrm{n}=1) \text {, out of touch }(\mathrm{n}=1) \text {, shy }(\mathrm{n}=1) \text {, geek }(\mathrm{n}=1)\end{array}$ \\
\hline $\begin{array}{l}\text { Engineers are } \\
\text { Motivated }\end{array}$ & $\begin{array}{l}\text { Response describes engineers } \\
\text { as being }\end{array}$ & Hardworking $(\mathrm{n}=22)$, motivated/ determined $(\mathrm{n}=16)$ \\
\hline Uncertainty & $\begin{array}{l}\text { Response demonstrates that } \\
\text { participant does not know how } \\
\text { to respond OR questions the } \\
\text { response }\end{array}$ & I don't know $(\mathrm{n}=9)$, questions own answer $(\mathrm{n}=4)$ \\
\hline
\end{tabular}


Table 6 is arranged such that the categories are listed in order by frequency of occurrence, with the most frequently occurring category listed at the top of the table. Figures 4 and 5 display the Wordles that were generated from the participants' responses to the open-ended survey responses

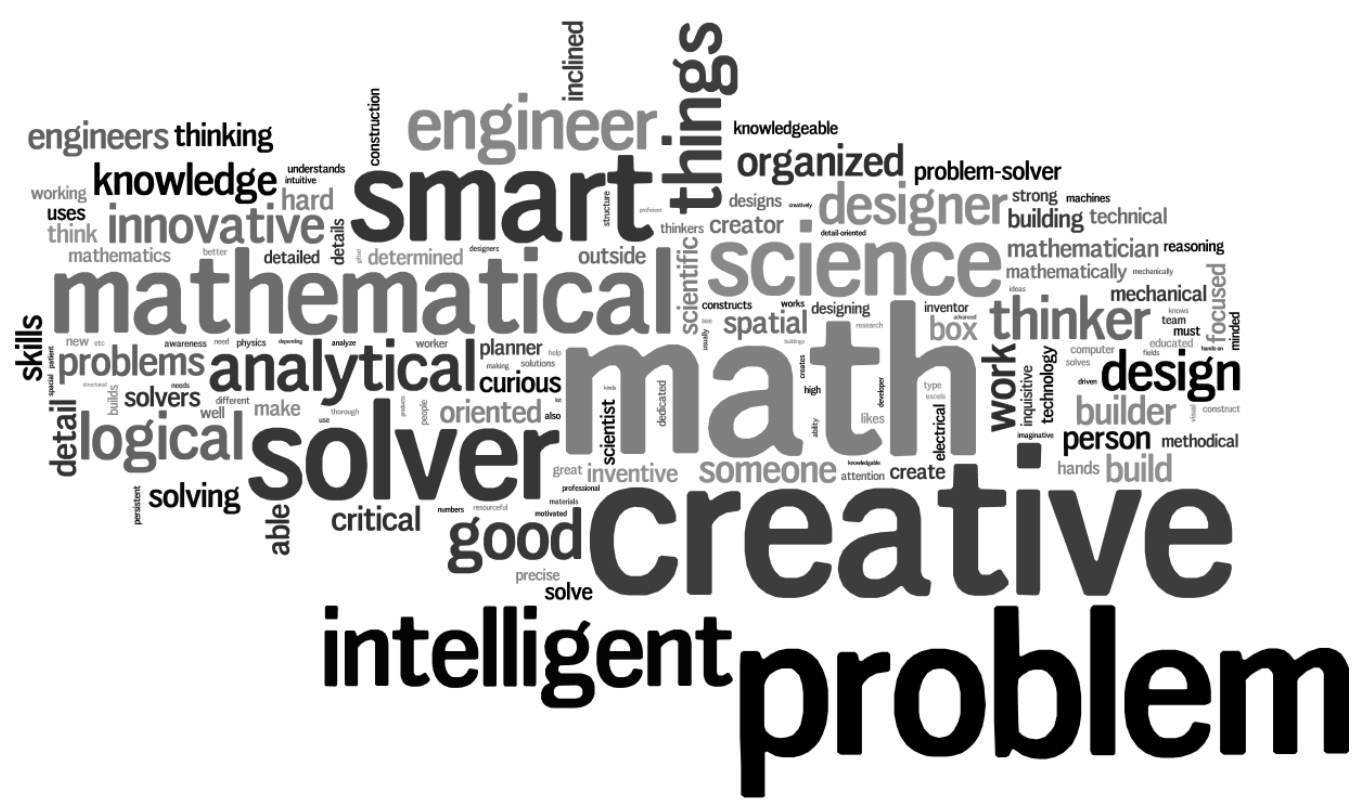

Figure 4. Wordle generated from participant responses to the survey question "What words or phrases would you use to describe the characteristics of a typical engineer?"

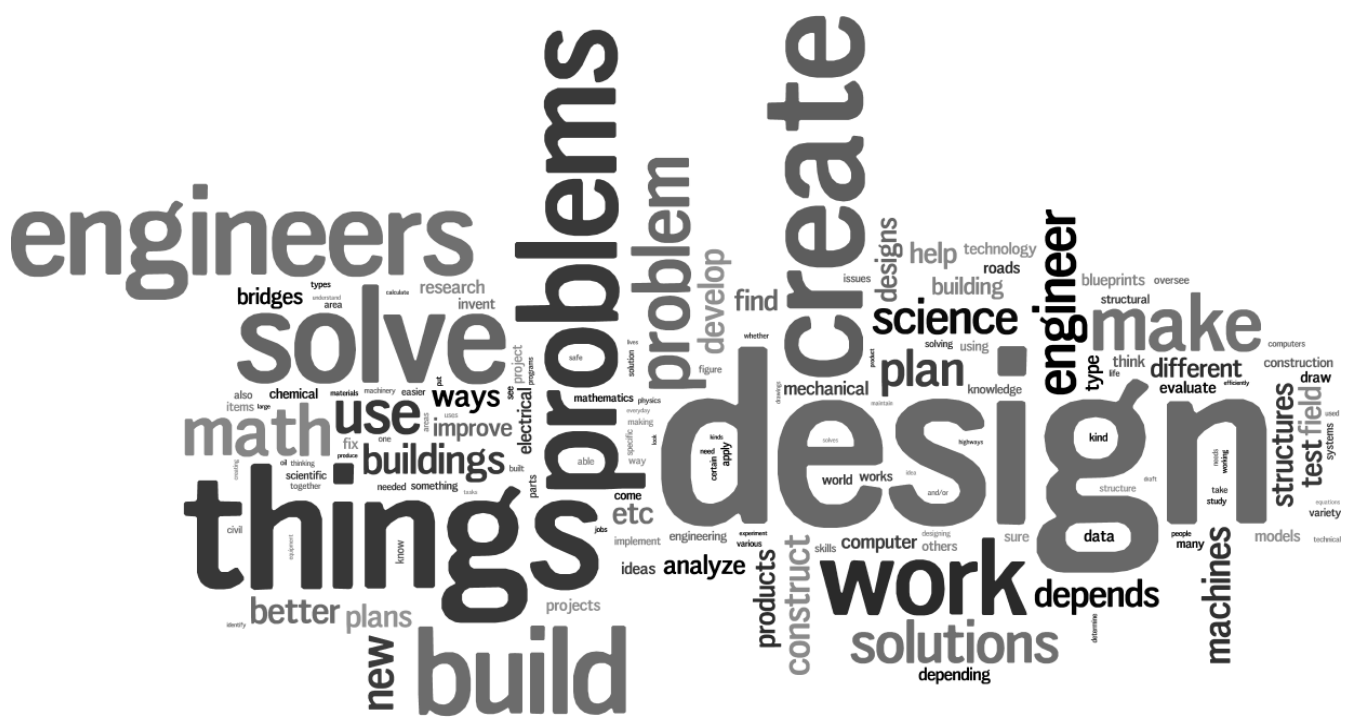

Figure 5. Wordle generated from participant responses to "What do engineers do as part of their work?"

Engineers as Thinkers

Words or phrases falling under the category of engineers as thinkers occurred 1,070 times. Participants described engineers as intelligent and mentioned engineers' abilities to use scientific knowledge. More than half of the participants described engineers as needing to know and use mathematics, writing things such as 
"Mathematical-minded; intelligent; likes to figure things out (a thinker!)" and "applying mathematical formulas to help solve problems." Engineers were frequently described as problem solvers, often in conjunction with the application of mathematics or science knowledge. Additional illustrative quotes were:

"An engineer is an individual who uses science and math to develop new technologies and products. An engineer must be well-educated in these fields in order to adequately design new equipment or materials. An engineer must be able to think creatively to come up with new innovations for old problems."

"A typical engineer applies scientific knowledge and math to creatively solve technical, commercial (ie infrastructure/bridges) and societal problems (Human engineering)."

"An engineer is a scientist who can build and solve problems. He/she is someone that works with numbers and science daily."

\section{Engineers as Creators}

The majority of responses in this category were single word answers or very short phrases that described engineers as being creative, designers, and inventors. Participants wrote statements such as "Create and design buildings," "Engineers are creators," "A person who creates things," "An engineer has creativity," and "Innovative."

\section{Engineers as Doers}

Responses in this category focused on physical or mechanical aspects of engineers' work. Many participants described engineers as people who construct, make, or build things; work on structures; or maintain and repair things. Example responses included "Engineers like to build things," "Build things and if it breaks, figures out a way to fix it," and "A person who builds engines."

\section{Engineers as Managers}

Engineers were also described as overseeing projects or as possessing the skills required to manage projects (i.e. organization, safety). Participants responses included "They are responsible for designing projects and overseeing their completion," "To be in charge and to manage or direct a group," and "Oversee that the project is going as planned."

\section{Engineers are Motivated}

Engineers were also described as hard working, determined, and motivated. Responses in this category were often single words or very short phrases, such as "Self-motivated," "Determined and a hard worker," and "The ability to scrap it and start again."

\section{Engineers are Technologically Savvy}

Engineers were described as being able to program or work with computers and good with technology. For example, engineers "Use computers to analyze and produce designs," "Develop computer programs," and "Have excellent computer skills to produce and analyze designs."

\section{Engineers as Social Beings}

This category included words or phrases that describe perceived personality traits or the ways that engineers interact with others. The perceived personality traits were often negative stereotypes, such as "Nerdy," "Anti-social behaviors," "Introverted," and "Out of touch." However, engineers were also described as "Team players" and "A team member who must communicate and listen accurately."

\section{Types of Engineers}

Sixty three participants mentioned that there are different types of engineers and their jobs vary depending on the type of engineer they are. Example responses in this category include: 
"It depends. They can be an engineer for the railroad, armed services, or robotics."

"It completely depends on the type of engineer. For a generalization I would say they come up with 'things' (depending on the type of engineer) and they test them. They have to be able to solve technical problems."

"I would imagine that an engineer would be in charge of chemical testing, design, instruction, and implementation of design. It would all depend on the field of study ie chemical, mechanical, or petroleum engineer."

"Engineer can mean many different things, depending on the field the engineer works in. A civil engineer and a chemical engineer do different tasks, but I believe both are focused on mathematics, science, and problem-solving."

"There are different types of engineers: some who design/create, some technical (who implement)."

Uncertainty. Some participants did not know how to describe engineers or the work they perform, making statements such as "Not really sure" and "I honestly do not know." Others gave responses but questioned their own statements, such as "Change things and make them better? I really don't know" and "Science and math calculations????" One participant quoted a TV character, "Engineers are the oompah loompahs of the science world.' - Sheldon Cooper." Another participant indicated that his/her participation in the study was due to a lack of understanding of engineering, "The term engineer is not clearly defined. That is why I decided to participate in this survey. I think that engineer is replacing the title of scientist, but I am not sure. Other teachers are not sure."

\section{Follow-up sessions}

Qualitative data from follow-up focus groups and interviews are presented below. For ease of reading, follow-up data are presented by the question being answered.

\section{What comes to mind when you think of an engineer?}

Responses to this question fell within the same categories as the open-ended survey questions, with most responses falling within multiple categories. One participant's response fell within Engineers as Thinkers, Engineers as Doers, Engineers as Social Beings, Engineers are Tech Savvy, and Types of Engineers, "Kind of nerdy but in a good way. I have some friends who are engineers. Really smart, building things, like civil engineers involved with water and dams and other types of engineers who build buildings and those types of things but again I have a friend who is a computer engineer and does computer stuff, so just kind of a whole lot of things." During the focus group, one participant mentioned that engineers are problem solvers, and another participant followed up with, "I had only heard that an engineer was a problem solver at a conference that I had been to, and I had never even thought of it in that way until you said that [referring to another focus group member] and then you think of all the different lines of engineering and that is the one thing that is in common is problem solving and so that kind of opened my eyes up too. That's been kind of a process for me to think about it in that way because you think about it more as building things, making things, or testing things, whether or not it's going to work before you actually do something."

\section{How would you describe your understanding of engineering?}

When asked to describe their personal understanding of engineering, most participants described their understanding as limited or developing, "Fairly limited. I've not taken any upper science. That's not something I took in my education or even my college years, so I would say it would be limited." One participant rated her knowledge on a scale, "On a scale from like 1 to 10, I would say I'm about a 5. I'm familiar with it. I can't tell you in depth about it." Two participants said their personal understanding of engineering was enhanced because their spouses were engineers, "Probably broader than most kindergarten teachers and early childhood teachers 
because of my husband. He comes home and talks about work."

\section{Do you use engineering activities in your classroom?}

To gain a better understanding of how familiar participants were with engineering, they were asked to describe any engineering activities they use in their classrooms. Most participants said they did not use any engineering activities with their students, other than using building blocks during centers. One participant described a unit on weights and measures as engineering, while another described a lab over phase changes as being engineering. One participant described an egg drop project she used. When asked if she talked about engineering during the egg drop project she responded, "I don't know that I have actually used the term engineering. We've talked about the science elements of what we are doing, like the energy side of it and building a structure that will withstand the forces you are trying to put on it, but I don't know that I have ever really used the term engineering with them."

\section{What do you know about the engineering design process?}

Most participants said that they knew very little or nothing at all about the design process. One participant stated, "I know nothing. I read it over and over again on the science standards and say okay engineering means that you find out that you need something, you need to design it, you need to create it, you need to find out what the flaws are, you need to redesign, but I don't know how to do that. I can say it but how do you put it into practice." Others were unsure of what the design process was and asked if it were similar to a scientific process, "Probably not a lot because I'm not familiar with what that is. Is it maybe kind of like a science process?" Another participant stated, "The scientific method is that what you're talking about? If it is different from the scientific method, then, I don't know." A few participants said that they felt they understood what the design process was but that they did not have the terminology required to teach it to their students. "I feel like I have enough knowledge...I think that a lot of the knowledge I need to teach it isn't specific enough. I need more help with the specific vocabulary...I feel like I have an understanding of the process they go through but to actually walk you through the steps and know what they are called, no." Another participant stated that the standards did not clearly describe what the design process was, "I probably do it and don't know it...I think terminology is the big issue. You know when I read through the standards last year when they started throwing them up my first reaction was 'What are they even talking about.' They wrote the standards for a Kindergarten teacher as if they were talking to $\mathrm{PhD}$ engineers. No, no, no, use the terminology that we are going to use and incorporate with our kids because otherwise you just scare and intimidate everybody."

\section{Discussion and Conclusions}

As previously stated, the purpose of this study was to (a) identify the perceptions that in-service elementary teachers hold about engineering and engineering design and (b) how those perceptions compare with the engineering practices described in NGSS. Findings are organized by research question.

Research Question 1: How familiar are in-service elementary teachers with engineering and engineering design?

Overall, K-5 teachers are unfamiliar with engineering or engineering design. Teachers reported their own knowledge of engineering as limited and scores on the Familiarity with DET subscale showed that participants had little previous coursework or training in engineering. Further, most participants said they were unfamiliar with what the engineering design process. Additionally, very few teachers reported using DET activities in their classroom. This was also seen in follow-up sessions when participants described the engineering activities they used in their classrooms. Of the few follow-up session participants who reported using engineering activities, most described activities that were actually science activities (e.g. weights and measures, phase changes) or described building with blocks. Building with blocks could fall under engineering 
if the teachers provided students with a problem they had to solve using the blocks, but none of the teachers who talked about blocks mentioned anything other than "building." Collectively, these results indicate that many K-5 teachers are not using engineering activities in the classroom and are not familiar enough with engineering to properly identify examples of engineering activities. This is not unexpected given that a previous national study only reported that $4 \%$ of elementary teachers felt prepared to teach engineering (Banilower et al., 2013). Further, because teachers are not comfortable teaching what they are unfamiliar with (Brophy et al., 2008) it is not surprising that few teachers in the study used engineering activities.

Research Question 2: What perceptions do in-service elementary teachers hold about engineers and engineering design?

Overall, elementary teachers in this study held stereotypical views about engineering as indicated by their responses on the DET, the open-ended questionnaire responses, and the follow-up sessions. Teachers often viewed engineers as being super smart with great math and science skills. Arguably, many engineers are intelligent and do well in math and science, however, it is interesting to note that fewer teachers identified engineers as having good communication skills and some mentioned negative social stereotypes such as "nerdy." When describing the work of engineers, many participants mentioned that engineers design or create, but it was also common for teachers to focus on physical aspects such as building and fixing machines. Likewise, Cunningham et al. (2006) found that K-6 teachers often viewed engineers as builders. Further, many teachers questioned their own understanding or stated that they did not know what engineers did for their work. Similar to the findings of previous studies (Hsu, Purzer, \& Cardella, 2011; Cunningham et al., 2006), elementary teachers in the current study had limited understanding of engineering design. Most of the follow-up participants stated that they did not know what engineering design was or they confused it with the scientific method. Others stated that they had read the standards but didn't understand what they meant or how to enact them. Together, these findings indicate that many elementary teachers hold misconceptions about engineers, engineering, and engineering design.

Research Question 3: Are there differences in teachers' familiarity with engineering or perceptions of engineers between different demographic groups?

ANOVA results for the Familiarity with DET and Stereotypical Characteristics of Engineering subscales were used to answer this question. The only significant difference for Familiarity with DET was gender, with males being more familiar with DET than females. While there was a large difference in sample sizes between males and females, the sample sizes were representative of the population and thought to be reliable. The significant difference found between males and females was not surprising, as previous research indicates that gender role socialization leads to boys having more STEM experiences than girls. Many family members, peers, teachers, and counselors reinforce masculine stereotypes of science (Ashbacher et al., 2010) and technology and encourage girls to pursue more feminine activities (Farmer, 2008). Counselors often steer girls into career paths that are more traditionally female and do not encourage as many girls to take advanced math, science, and technology courses (Farmer, 2008).

There were no significant differences between demographic groups for perceptions of engineers, as measured by the Stereotypical Characteristics of Engineering subscale, indicating that teachers in this study held the same misconceptions about engineers regardless of demographic group. This suggests that stereotypical misconceptions of engineers are widespread and need to be addressed across all demographic groups.

Research Question 4: How do in-service elementary teachers' perceptions of engineers and engineering design compare with expectations set by K-5 engineering education standards?

NGSS analysis revealed that the engineering standards to be taught in K-5 classrooms fall under the topics of engineering design and engineers' impact on society. In order to teach these standards, teachers 
must understand engineering design as well as pedagogical strategies for implementing design activities into the classroom. They must also have a basic understanding of how the work of engineers impacts society. Participants' responses on the questionnaire and follow-up sessions revealed that elementary teachers hold misconceptions about engineering which may impact the way they view the work of engineers and impact the way they teach engineering to their students. Teachers also have a limited understanding of engineering design, as well as limited experiences using engineering design with their students. Having fewer experiences using engineering design activities limits teachers' opportunities to build the pedagogical strategies required to successfully implement the standards related to engineering.

\section{Implications and future research}

Findings form this study indicate that elementary teachers are not prepared to incorporate engineering practices in their classrooms. Teachers are unfamiliar with the work of engineers and the engineering design process and have little experience teaching engineering design. Before teachers can successfully incorporate engineering practices into their classrooms they will need training in how to distinguish between science and engineering practices, as well as how to infuse engineering design elements into developmentally appropriate lessons that also incorporate science content, knowledge of engineers, and career awareness. This will require professional development experiences to support teachers in strengthening their content knowledge, curricular knowledge, and pedagogical content knowledge related to engineering. Further research is needed to determine the ways to best deliver engineering focused professional development to elementary teachers. In the meantime, teacher preparation programs and providers of professional development need to identify current engineering education training programs that are available for teachers as well as work to develop and pilot programs that target these areas of need. Further, administrators need to be aware of these findings and work to identify available resources for their teachers as well as ways to fund needed training.

With the need to ensure that all students are provided multiple opportunities to develop STEM literacy and problem-solving skills, it is imperative that elementary teachers receive proper training in order to successfully implement engineering content and practices into their classrooms. This will require quality ongoing training that addresses what engineering is and how to differentiate between science and engineering activities, as well as provide teachers with the tools to incorporate engineering into their classrooms and go beyond teaching engineering as building with blocks.

Disclaimer: The views and opinions of the authors expressed herein do not necessarily state or reflect those of the U.S. Government or any agency thereof.

\section{References}

Aschbacher, P. R., Li, E., \& Roth, E. J. (2010). Is science me? High school students' identities, participation and aspirations in science, engineering, and medicine. Journal of Research in Science Teaching, 47(5), 564582. doi:10.1002/tea.20353

Baker, D., Yasar-Purzer, S., Kurpius, S., Krause, S., \& Roberts, C. (2007). Infusing design, engineering and technology into K-12 teachers' practice. International Journal of Engineering Education, 23(5), 884-893. Retrieved from http://www.ingentaconnect.com/content/intjee/ijee

Banilower, E. R., Smith, P. S., Weiss, I. R., Malzahn, K. A., Campbell, K. M., \& Weis, A. M. (2013). Report of the 2012 national survey of science and mathematics education. Chapel Hill, NC: Horizon Research, Inc.

Bischoff, P. J. (2006). The role of knowledge structures in the ability of preservice elementary teachers to diagnose a child's understanding of molecular kinetics. Science Education, 90(5), 936-951. doi: 10.1002/ sce. 20155 
Brinkmann, S. (2013). Qualitative interviewing: Understanding qualitative research. New York, NY: Oxford University Press.

Brophy, S., Klein, S., Portsmore, M., \& Rogers, C. (2008). Advancing engineering education in P-12 classrooms. Journal of Engineering Education, 97(3), 369-387. doi: 10.1002/j.2168-9830.2008.tb00985.x

Carberry, A. R., Lee, H.-S., \& Ohland, M. W. (2010). Measuring engineering design self-efficacy. Journal of Engineering Education, 99(1), 71-79. doi: 10.1002/j.2168-9830.2010.tb01043.x

Committee on Standards for K-12 Engineering (2010). Standards for K-12 Engineering Education? Washington, DC: The National Academies Press.

Creswell, J. W. (2007). Qualitative inquiry \& research design: Choosing among five approaches (2nded.). Thousand Oaks, CA: Sage Publications.

Creswell, J. W., \& Plano Clark, V. L. (2011). Designing and conducting mixed methods research (2nd ed.). Los Angeles, CA: Sage Publications.

Cunningham, C. (2009). Engineering is elementary. The Bridge: Linking Engineering and Society, 39(3), 11-17. Retrieved from http://www.nae.edu/TheBridge

Cunningham, C., Lachapele, C., \& Lindgren-Stricher, A. (2006). Elementary teachers' understandings of engineering and technology. Proceedings of the 2006 American Society for Engineering Education Annual Conference \& Exposition, Chicago, IL.

Cunningham, C. M., Lachapelle, C. P., \& Lindgren-Streicher, A. (2005). Assessing elementary school students' conceptions of engineering and technology. Paper presented at the ASEE Annual Conference, Portland, OR.

Davis, E. A. (2003). Knowledge integration in science teaching: Analyzing teachers' knowledge development. Research in Science Education, 34(1), 21-53. doi: 10.1023/B:RISE.0000021034.01508.b8

Farmer, L. (2008). Teen girls and technology: What's the problem, what's the solution? New York, NY: Teachers College Press.

Fralick, B., Kearn, J., Thompson, S., \& Lyons, J. (2009). How middle schoolers draw engineers and scienctists. Journal of Science Education and Technology, 18(1), 60-73. doi: 10.1007/s10956-008-9133-3

Guzey, S. S., Tank, K., Wang, H. H., Roehrig, G., \& Moore, T. (2014). A high quality professional development for teachers of grades 3-6 for implementing engineering into classrooms. School Science and Mathematics, 114(3), 139-149. doi:10.111/ssm.12061

Hammack, R., \& High, K. (2014). Effects of an after school engineering mentoring program on middle school girls' perceptions of engineers. Journal of Women and Minorities in Science and Engineering, 20(1), 1120. doi: 10.1615/JWomenMinorScienEng. 2014006726

Harlen, W., \& Holroyd, C. (1997). Primary teachers' understanding of concepts of science: Impact on confidence and teaching. International Journal of Science Education, 19(1), 93-105. doi: 10.1080/0950069970190107

Hsu, M.; Purzer, S.; and Cardella, M. E. (2011). Elementary teachers' views about teaching design, engineering, and technology. Journal of Pre-College Engineering Education Research, 1(2), 31-39. doi: $10.5703 / 1288284314639$

Karatas, F. O., Micklos, A., \& Bodner, G. M. (2011). Sixth-grade students' views of the nature of engineering and images of engineers. Journal of Science and Education Technology, 20, 123-135. doi: 10.1007/s10956010-9239-2

Knight, M., \& Cunningham, C. (2004). Draw an Engineer Test (DAET): Development of a tool to investigate students' ideas about engineers and engineering. Proceedings of the 2004 American Society for Engineering Education Annual Conference \& Exposition, Salt Lake City, UT. 
Lambert, M., Diefes-Dux, H., Beck, M., Duncan, D., Oware, E., \& Nemeth, R. (2007). What is engineering? - Am exploration of P-6 grade teachers' perspectives. Proceedings of the 2007 American Society for Engineering Education Annual Conference \& Exposition, Milwaukee, WI.

Liu, W., Carr, R., \& Strobel, J. (2009). Extending teacher professional development through an online learning community: A case study. Journal of Educational Technology Development and Exchange, 2(1), 99-112. Retrieved from http://www.sicet.org/journals/jetde/jetde09/wei.pdf

McNaught, C., \& Lam, P. (2010). Using wordle as a supplementary research tool. The Qualitative Report, 15(3), 630-643. Retrieved from http://nsuworks.nova.edu/tqr/vol15/ iss3/8

Merriam, S. B. (2009). Qualitative research: A guide to design and implementation. San Francisco, CA: JosseyBass.

Namey, E., Guest, G., Thairu, L., \& Johnson, L. (2008). Data reduction techniques for large qualitative data sets. In G. Guest \& K.M. MacQueen (Eds.), Handbook for team-based qualitative research (pp. 137-61). Lanham, MD: AltaMira Press.

National Research Council. (2012). A framework for K-12 science education: Practices, crosscutting concepts, and core ideas. Committee on a Conceptual Framework for New K-12 Science Education Standards. Board on Science Education, Division of Behavioral and Social Sciences and Education. Washington, DC: The National Academies Press.

NGSS Lead States. (2013). Next Generation Science Standards: For states, by states. Washington, DC: The National Academies Press.

Newley, A., Kaya, E., Yesilurt, E. \& Denzin, H. (2017). Measuring engineering perceptions of fifth-grade minority students with the draw-an-engineer-test (DAET). Proceedings of the 2017 American Society for Engineering Education Annual Conference \& Exposition, Columbus, $\mathrm{OH}$.

Oliver, D. G., Serovich, J. M., \& Mason, T. L. (2005). Constraints and opportunities with interview transcription: Towards reflection in qualitative research. Social Forces, 84(2), 1273-1289. Retrieved from http://www. jstor.org/stable/3598499

Oware, E., Capobianco, B., \& Diefes-Dux, H.A. (2007). Young children's perceptions of engineers before and after a summer engineering outreach course. Presentation at the 37th Annual ASEE/IEEE Frontiers in Education Conference, Milwaukee, WI.

Patten, M. L. (2001). Quantitative research: A practical guide (2 ${ }^{\text {nd }}$ ed.). Los Angeles, CA: Pyrczak Publishing.

Pekmez, E. (2018). Primary school students' views about science, technology and engineering. Educational Research and Reviews, 13(2), 81-91. doi: 10.5897/ERR2017.3429

Petroski, H. (2003). Engineering: Early education. American Scientist, 91(3), 206-209. Retrieved from http:// www.jstot.org/stable/27858205

Saldana, J. (2013). The coding manual for qualitative researchers ( $2^{\text {nd }} e d$.). Thousand Oaks, CA: Sage Publications.

Sargianis, K., Yang, S., \& Cunningham, C. M. (2012). Effective engineering professional development for elementary educators. Proceedings of the 2012 American Society for Engineering Education Annual Conference \& Exposition, San Antonio, TX.

Schunn, C. (2009). How kids learn engineering: The cognitive science. The Bridge: Linking Engineering and Society, 39(3), 32-37. Retrieved from http://www.nae.edu/TheBridge

Shulman, L. S. (1986). Those who understand: Knowledge growth in teaching. Educational Researcher, 15(2), 4-14. Retrieved from http://www.jstor.org/stable/1175860

Silk, E. M., \& Schunn, C. D. (2008, January). Core concepts in engineering as a basis for understanding and improving K-12 engineering education in the United States. In National Academy of Engineering/ National Research Council workshop on k-12 engineering Education, Washington, DC. 
Van Haneghan, J. P., Pruet, S. A., Neal-Waltman, R., \& Harlan, J. M. (2015). Teacher beliefs about motivating and teaching students to carry out engineering design challenges: Some initial data. Journal of PreCollege Engineering Education Research, 5(2), 1-9. doi: 10.7771/2157-9288.1097

Yasar, S., Baker, D., Kurpius-Robinson, S., Krause, S., \& Roberts, C. (2006). Development of a survey to assess K-12 teachers' perceptions of engineers and familiarity with teaching design, engineering, and technology. Journal of Engineering Education, 95(3), 205-216. doi: 10.1002/j.2168-9830.2006.tb00893.x

Yoon Yoon, S. Evans, M. G., \& Strobel, J. (2014). Validation of the teaching engineering self-efficacy scale (TESS) for K-12 teachers: A structural equation modeling approach. Journal of Engineering Education, 103(3), 463-485. doi: 10.1002/jee.20049 
Appendix A

DET Questions

Definition of Design/Engineering/Technology (DET) The term "technology," as used in the national science standards, implies the design, engineering, and the technological issues related to conceiving, building, maintaining, and disposing of the useful objects and/or processes in the human-built world. Sometimes this term is referred to as "technological education," but, please note that it is separate from the use of computers and educational technology in the classroom. It is also distinctly different from job training or vocational education. In this questionnaire, we use the term "Design/Engineering/Technology" or DET, synonymously with what the national science education standards (NRC, 1996) call "technology." DET encompasses a number of concepts and skills, including the ability to: identify a problem or a need to improve on current technology, propose a problem solution - solutions may be conceptual or physical objects, identify the costs and benefits of solutions, select the best solution from among several proposed choices by comparing a given solution to criteria it was designed to meet, implement solutions by building a model or a simulation, communicate the problem, the process and the solution in various ways. Examples of different Design/Engineering/Technology (DET) functions include: Designing activities for a school outing. Building a paper bridge that will support a weight, Designing the layout of a new playground, Inventing a new device or process, Designing and piloting a new device or process, Analyzing the economics of two different types of paper towels in absorbing water, Building working models of devices or processes Please answer the following questions, choosing the most appropriate answer ( $1=$ Not at all, $5=$ Very Much).

\begin{tabular}{|l|l|l|l|l|l|}
\hline $\begin{array}{l}\text { How familiar are you with Design/Engineering/Technology as typically } \\
\text { demonstrated in the examples given on the previous page? }\end{array}$ & 1 & 2 & 3 & 4 & 5 \\
\hline $\begin{array}{l}\text { Have you had any specific courses in Design/Engineering/Technology } \\
\text { outside of your preservice curriculum? }\end{array}$ & 1 & 2 & 3 & 4 & 5 \\
\hline $\begin{array}{l}\text { Did your preservice curriculum include any aspects of Design/Engineer- } \\
\text { ing/Technology? }\end{array}$ & 1 & 2 & 3 & 4 & 5 \\
\hline $\begin{array}{l}\text { Was your preservice curriculum effective in supporting your ability to } \\
\text { teach Design/Engineering/Technology at the beginning of your career? }\end{array}$ & 1 & 2 & 3 & 4 & 5 \\
\hline $\begin{array}{l}\text { How confident do you feel about integrating more Design/Engineering/ } \\
\text { Technology into your curriculum? }\end{array}$ & 1 & 2 & 3 & 4 & 5 \\
\hline Do you use Design/Engineering/Technology activities in the classroom? & 1 & 2 & 3 & 4 & 5 \\
\hline Does your school support Design/Engineering/Technology activities? & 1 & 2 & 3 & 4 & 5 \\
\hline To what extent do you agree that a typical engineer...(1= strongly disagree, 5= strongly agree) & 1 & 2 & 3 & 4 & 5 \\
\hline Works well with people & 1 & 2 & 3 & 4 & 5 \\
\hline Has good verbal skills & 1 & 2 & 3 & 4 & 5 \\
\hline Has good math skills & 1 & 2 & 3 & 4 & 5 \\
\hline Has good writing skills & 1 & 2 & 3 & 4 & 5 \\
\hline Earns good money & 1 & 2 & 3 & 4 & 5 \\
\hline Likes to fix things & 1 & 2 & 3 & 4 & 5 \\
\hline Does well in science
\end{tabular}

